\title{
Microstructure and Tensile Strength of Foamed Concrete with Added Polypropylene Fibers
}

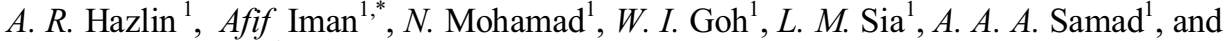 \\ Noorwirdawati Ali ${ }^{1}$ \\ ${ }^{1}$ Department of Structure and Material Engineering, Faculty of Civil and Environmental Engineering, \\ Universiti Tun Hussein Onn Malaysia, Parit Raja, 86400 Batu Pahat, Johor, Malaysia
}

\begin{abstract}
An experimental study was conducted to improve the strength of foamed concrete by adding fibres reinforced material, polypropylene (PP) fibres. The aim of the study was to determine the effect of PP fibres on the microstructure and tensile strength of foamed concrete. Foamed concrete with density $1600 \mathrm{~kg} / \mathrm{m}^{3}$ and $1800 \mathrm{~kg} / \mathrm{m}^{3}$ were cast and tested with $0.05 \%, 0.10 \%$ and $0.15 \%$ percentage of PP fibres. The findings shows that foamed concrete added by PP fibres gave better performance in tensile strength compared to foamed concrete without PP fibres. With the addition of $0.05 \%$ of PP fibres, the tensile strength increased by $35.06 \%$ and $40.30 \%$ for foamed concrete with densities $1600 \mathrm{~kg} / \mathrm{m}^{3}$ and 1800 $\mathrm{kg} / \mathrm{m}^{3}$, respectively. Through the study of microstructure of foamed concrete, the air voids of foamed concrete with various densities and the interfacial adhesion between concrete and fibres were observed. The foamed concrete added by PP fibres gave better performance in tensile strength compared to foamed concrete without PP fibres.
\end{abstract}

\section{Introduction}

Foamed concrete is lightweight and has lower density compared to normal concrete. With its advantage of low density, foamed concrete imposes little stress on the substructure. Among its many advantages is it can be used as a viable solution for reducing load on burdened soil, a particularly important issue in settlement.

However, despite the attractive advantages of foamed concrete, only limited data exists on its performance and guidance on its applications. Foamed concrete has a compressive strength between $1 \mathrm{MPa}$ to $10 \mathrm{MPa}$ [1]. The lack of coarse aggregate in formed concrete makes it prone to any types of shrinkage cracks. Therefore, it has lower strength compare to normal concrete.

Cracks play an important role in concrete as they change concrete structure into permeable element and has a high risk of corrosion. Cracks will reduce the quality of concrete and make the structure out of service [2]. Therefore, it is important to reduce the crack width by adding fibres. PP fibres has been used into admixture of concrete which can

\footnotetext{
*Corresponding author: noridah@uthm.edu.my
} 
increase the tensile strength and mainly improve the prevention of post cracking that begin at micro cracking The structural of concrete such as shear resistance, bond strength and resistance to cracking depend on the tensile strength; the higher the tensile strength the better the structural properties [3].

In order to minimize the crack and increase the tensile strength of foamed concrete, PP fibres was added as additives. The percentages of PP fibres which was added in this research were $0.05 \%, 0.10 \%$ and $0.15 \%$ of the total volume of foamed concrete with densities $1600 \mathrm{~kg} / \mathrm{m}^{3}$ and $1800 \mathrm{~kg} / \mathrm{m}^{3}$.

\section{Materials and method}

\subsection{Materials and mixture composition}

The materials used in the foamed concrete admixture are Ordinary Portland cement (OPC), dried sand pass through $3 \mathrm{~mm}$, foam and water. The foam agent used to produce foam is SikaAER-50/50. The stable foam was produced with one portion of foam agent and twenty portion of water. In this study, the density of foamed concrete was fixed as $1600 \mathrm{~kg} / \mathrm{m}^{3}$ and $1800 \mathrm{~kg} / \mathrm{m}^{3}$. The sand $/$ cement and water/cement ratios chosen in this study were 2 and 0.55 , respectively.

\subsection{Polypropylene fibres properties}

Fibrillated PP fibres with $12 \mathrm{~mm}$ of length was used in this study. Fibrillated PP consists of interconnected fibres strand that open during mixing [4]. The fibrillated fibres reduce plastic shrinkage and permeability, to increase impact resistance, abrasion resistance fatigue and cohesiveness [5]. Characteristic tensile strength of PP fibres is $300 \mathrm{~N} / \mathrm{mm}^{2}$ with 900 $\mathrm{kg} / \mathrm{m}^{3}$ density [6]. In this study, dosage $0.05 \%, 0.10 \%$ and $0.15 \%$ of PP fibres by volume were added into each sample of foamed concrete with density $1600 \mathrm{~kg} / \mathrm{m}^{3}$ and $1800 \mathrm{~kg} / \mathrm{m}^{3}$ respectively.

\subsection{Experimental test procedures}

OPC, fine sand, water and PP fibres were batched and mixed in a concrete mixer. The foam was added gradually in the mixture according to BS EN 12350-6 [7] until the targeted density was achieved. The mixed foamed concrete was poured into the mould and were cured in room temperature.

Splitting tensile test was performed in accordance with BS-EN-12390-6 [8]. An axial load with a specified rate of loading was applied to cylinder with diameter of $150 \mathrm{~mm}$ and height of $300 \mathrm{~mm}$ until failure. Mean value obtained from three cylinders were then took as splitting tensile strength for each foamed concrete mixture at age of 28 days.

Microstructural image analysis was carried out by means of Scanning Electron Microscope (SEM). SEM is used for the examination and analysis of microstructural characteristics of solid objects. High resolution can be obtained when a bulk objects are examined [9]. A small piece of crushed foamed concrete from the tested cylinder was used for microstructure analysis. 


\section{Results and discussion}

\subsection{Density}

It was noticed that most samples had higher density compared to the target density as shown in Table 1 and Table 2. It was difficult to achieve the target density since there were a lot of unpredictable elements during mixing work and environments factors. The production of stable foamed concrete mix is depends on many factors which were, selection of foaming agent, method of foam preparation and addition for uniform air-voids distribution, material section and mixture design strategies, production of foamed concrete, and performance with respect to fresh and hardended state were of great significance [10].

Table 1. Actual density of $1600 \mathrm{~kg} / \mathrm{m}^{3}$ foamed concrete samples for cylinder.

\begin{tabular}{|c|c|c|c|c|c|c|}
\hline $\begin{array}{c}\text { Fibres } \\
\text { Content }\end{array}$ & \multicolumn{2}{|c|}{ Specimen } & $\begin{array}{c}\text { Volume } \\
\left(\mathrm{m}^{3}\right)\end{array}$ & $\begin{array}{c}\text { Weight } \\
\text { (kg) }\end{array}$ & $\begin{array}{l}\text { Density } \\
\left(\mathrm{kg} / \mathrm{m}^{3}\right)\end{array}$ & $\begin{array}{l}\text { Average } \\
\left(\mathrm{kg} / \mathrm{m}^{3}\right)\end{array}$ \\
\hline \multirow{3}{*}{$0 \%$} & \multirow{3}{*}{ AControl } & 1 & 0.0053 & 9.18 & 1732 & \multirow{3}{*}{1734} \\
\hline & & 2 & 0.0053 & 9.15 & 1726 & \\
\hline & & 3 & 0.0053 & 9.24 & 1743 & \\
\hline \multirow{3}{*}{$0.05 \%$} & \multirow{3}{*}{ APP01 } & 1 & 0.0053 & 9.30 & 1755 & \multirow{3}{*}{1752} \\
\hline & & 2 & 0.0053 & 9.23 & 1741 & \\
\hline & & 3 & 0.0053 & 9.33 & 1760 & \\
\hline \multirow{3}{*}{$0.10 \%$} & \multirow{3}{*}{ APP02 } & 1 & 0.0053 & 9.25 & 1745 & \multirow{3}{*}{1753} \\
\hline & & 2 & 0.0053 & 9.28 & 1751 & \\
\hline & & 3 & 0.0053 & 9.35 & 1764 & \\
\hline \multirow{3}{*}{$0.15 \%$} & \multirow{3}{*}{ АРP03 } & 1 & 0.0053 & 9.84 & 1857 & \multirow{3}{*}{1862} \\
\hline & & 2 & 0.0053 & 9.83 & 1855 & \\
\hline & & 3 & 0.0053 & 9.93 & 1874 & \\
\hline
\end{tabular}

Table 2. Actual density of $1800 \mathrm{~kg} / \mathrm{m}^{3}$ foamed concrete samples for cylinder.

\begin{tabular}{|c|c|c|c|c|c|c|}
\hline $\begin{array}{c}\text { Fibres } \\
\text { Content }\end{array}$ & \multicolumn{2}{|c|}{ Specimen } & $\begin{array}{c}\text { Volume } \\
\left(\mathrm{m}^{3}\right)\end{array}$ & $\begin{array}{c}\text { Weight } \\
(\mathrm{kg})\end{array}$ & $\begin{array}{l}\text { Density } \\
\left(\mathrm{kg} / \mathrm{m}^{3}\right)\end{array}$ & $\begin{array}{l}\text { Average } \\
\left(\mathrm{kg} / \mathrm{m}^{3}\right)\end{array}$ \\
\hline \multirow{3}{*}{$0 \%$} & \multirow{3}{*}{ BControl } & 1 & 0.0053 & 10.17 & 1919 & \multirow{3}{*}{1928} \\
\hline & & 2 & 0.0053 & 10.20 & 1924 & \\
\hline & & 3 & 0.0053 & 10.29 & 1941 & \\
\hline \multirow{3}{*}{$0.05 \%$} & \multirow{3}{*}{ ВРP01 } & 1 & 0.0053 & 10.73 & 2024 & \multirow{3}{*}{2013} \\
\hline & & 2 & 0.0053 & 10.65 & 2009 & \\
\hline & & 3 & 0.0053 & 10.63 & 2006 & \\
\hline \multirow{3}{*}{$0.10 \%$} & \multirow{3}{*}{ ВРP02 } & 1 & 0.0053 & 10.48 & 1977 & \multirow{3}{*}{1970} \\
\hline & & 2 & 0.0053 & 10.45 & 1972 & \\
\hline & & 3 & 0.0053 & 10.39 & 1960 & \\
\hline \multirow{3}{*}{$0.15 \%$} & \multirow{3}{*}{ ВРР03 } & 1 & 0.0053 & 10.72 & 2023 & \multirow{3}{*}{2019} \\
\hline & & 2 & 0.0053 & 10.72 & 2023 & \\
\hline & & 3 & 0.0053 & 10.66 & 2011 & \\
\hline
\end{tabular}

\subsection{Tensile strength}

The results of testing the split tensile strength of foamed concrete with PP fibres addition using cylindrical specimen, diameter $150 \mathrm{~mm}$, height $300 \mathrm{~mm}$ can be seen in Table 3 . 
Table 3. Result of split tensile strength.

\begin{tabular}{|c|c|c|c|c|}
\hline \multirow{2}{*}{$\begin{array}{c}\text { Target } \\
\text { Density }\left(\mathrm{kg} / \mathrm{m}^{3}\right)\end{array}$} & \multicolumn{4}{|c|}{ Average Split Tensile Strength (MPa) } \\
\cline { 2 - 5 } & Control & PP01 & PP02 & PP03 \\
\hline $1600($ Set A) & 0.77 & 1.04 & 0.9 & 1.24 \\
\hline $1800($ Set B) & 1.34 & 1.88 & 1.8 & 1.7 \\
\hline
\end{tabular}

From Fig. 1, the result obtained for the control specimens shows a huge different in split tensile strength. The result for tensile strength of target density $1600 \mathrm{~kg} / \mathrm{m}^{3}$ foamed concrete is $0.77 \mathrm{MPa}$, while tensile strength of target density $1800 \mathrm{~kg} / \mathrm{m}^{3}$ foamed concrete is $1.34 \mathrm{MPa}$. It shows an increment of $0.57 \mathrm{MPa}$. The increase occurs due to the increasing density and decreasing foam volume. The strength of foamed concrete appeared to increase exponentially with an increase in concrete density or with a decrease in foam volume [11].

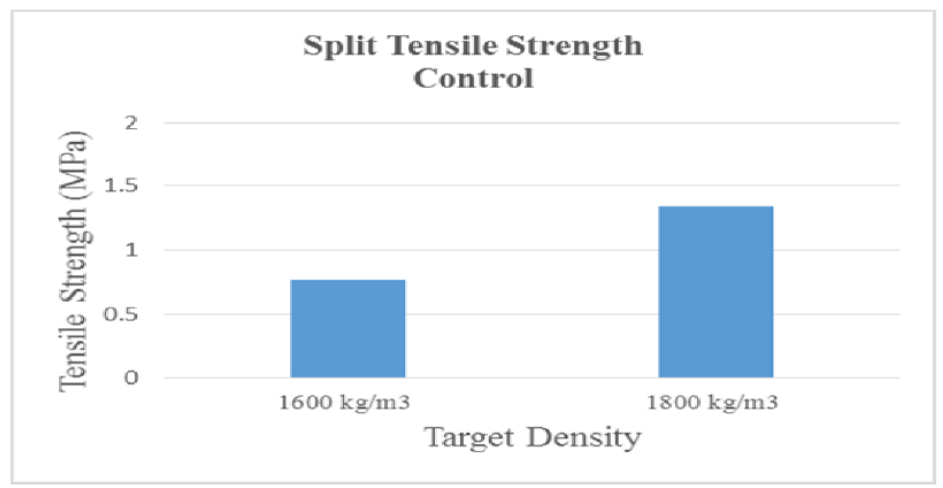

Fig. 1. The tensile strength versus density

From the Fig. 2, we can see that the tensile strength of foamed concrete with target density $1800 \mathrm{~kg} / \mathrm{m}^{3}$ (Set B) is higher compare to foamed concrete with target density $1600 \mathrm{~kg} / \mathrm{m}^{3}$ (Set A). Therefore, the effect of density and foam volume on the strength of foamed concrete can clearly see from this figure. The higher the density of foamed concrete, the higher its strength.

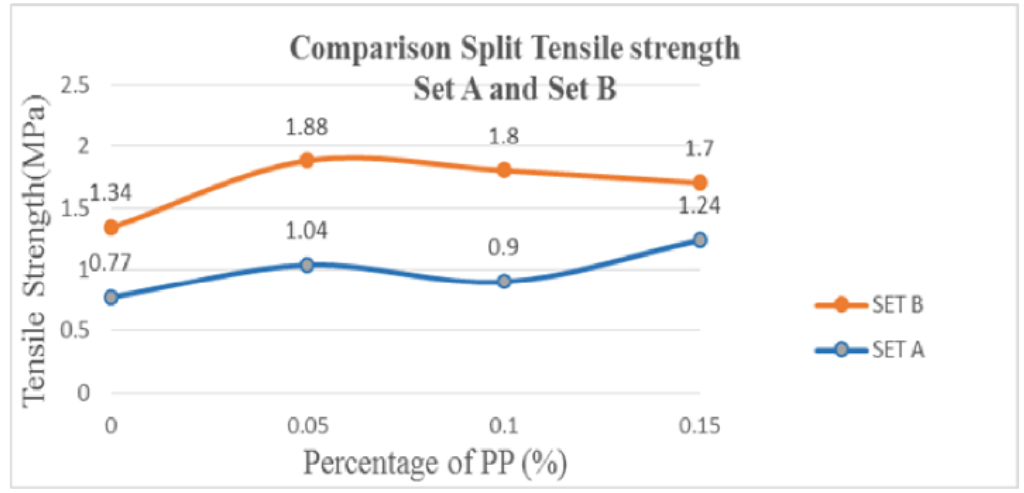

Fig. 2. The tensile strength of foamed concrete with target density $1600 \mathrm{~kg} / \mathrm{m}^{3}$ (set A) and $1800 \mathrm{~kg} / \mathrm{m}^{3}$ (set B) versus percentage of PP fibres. 
Both foamed concrete with density $1600 \mathrm{~kg} / \mathrm{m}^{3}$ and $1800 \mathrm{~kg} / \mathrm{m}^{3}$ show the peak reading of tensile strength when $0.05 \%$ fibres content was added. However, for foamed concrete with density $1600 \mathrm{~kg} / \mathrm{m}^{3}$, another peak reading of tensile strength was noticed when $0.15 \%$ fibres was added. Foamed concrete with density $1600 \mathrm{~kg} / \mathrm{m}^{3}$ and added $0.15 \%$ fibres (APP03) was found to have higher strength compared to other specimen in Set A.

From Fig. 2, for foamed concrete with both densities, the PP fibres content for optimum tensile strength is found to be $0.05 \%$. The research carried by Jones \& McCarthy (2005) and Chen Bing et al (2012) recommended much higher percentage of PP content to be added to achieve the higher strength of foamed concrete which are $0.50 \%$ and $0.80 \%$, respectively [11]. However, type of PP fibres used in foamed concrete carried out by previous researcher mostly was monofilament fibres. According to Medina et al (2015), the use of $0.07 \%$ fibrillated fibres in normal concrete was found to have maximum cracking control. Larger amount of PP fibres did not improve cracking control [12]. Therefore, it was reasonable that the optimum percentage of PP fibres as additive in foamed concrete for both $1600 \mathrm{~kg} / \mathrm{m}^{3}$ and $1800 \mathrm{~kg} / \mathrm{m}^{3}$ density was $0.05 \%$.

\subsection{Microstructure}

Fig. 3 shows the air voids in foamed concrete without fibres for densities $1600 \mathrm{~kg} / \mathrm{m}^{3}$.and $1800 \mathrm{~kg} / \mathrm{m}^{3}$. Both figure had the same scale which was $35 \mathrm{x}$. The air voids of $1600 \mathrm{~kg} / \mathrm{m}^{3}$ foamed concrete was found to have bigger size compared to $1800 \mathrm{~kg} / \mathrm{m}^{3}$ foamed concrete. The greater the air content the lower the density. This is why the foamed concrete of 1600 $\mathrm{kg} / \mathrm{m}^{3}$ density has the bigger voids size compared to the foamed concrete of $1800 \mathrm{~kg} / \mathrm{m}^{3}$.

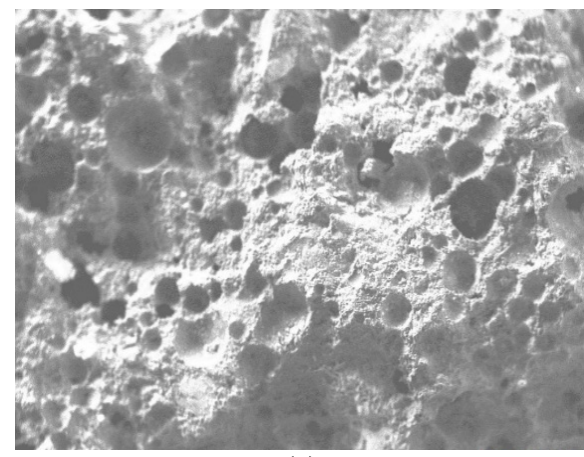

(a)

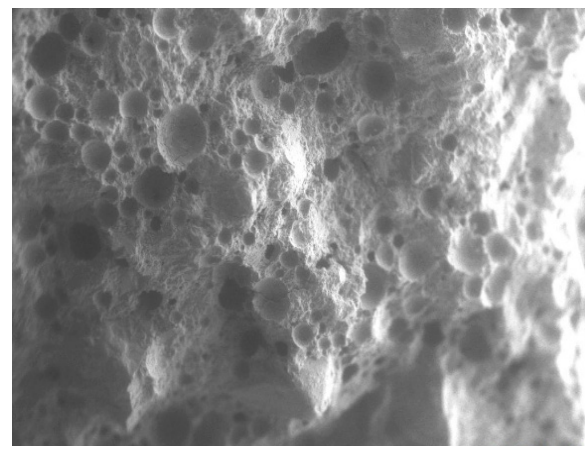

(b)

Fig. 3. Air voids in foamed concrete (35x): (a) $1600 \mathrm{~kg} / \mathrm{m}^{3}$ density - AControl (b) $1800 \mathrm{~kg} / \mathrm{m}^{3}-$ Bcontrol.

Fig. 4 shows the microstructure of foamed concrete with density $1600 \mathrm{~kg} / \mathrm{m}^{3}$ without fibres and with fibres which has scale factor of 300x. From the high resolution image, the microstructure of foamed concrete without fibres was observed to have micro porous and rough surface in the Fig. 4(a). Fig. 4(b) shows the microstructure of foamed concrete with fibres, the interfacial bonding between PP fibres and matrix was observed in the figure within the red circle. The foamed concrete around fibres usually dense due to fibrillated process and interfacial adhesion. The bubbles formed in the matrix of foamed concrete produce micro porous and hence reduce the interfacial bonding in the matrix. Hence, the presence of PP fibres in foamed concrete play role to bridging force crossing crack of matrix and reduce the micro crack [13]. 


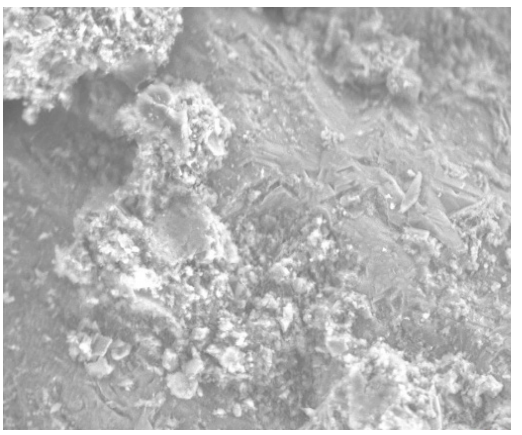

(a)

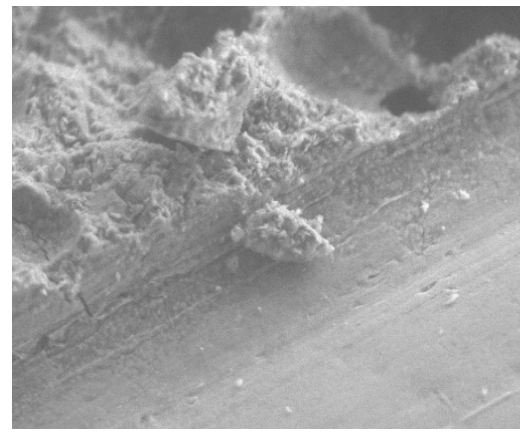

(b)

Fig. 4. Microstructure of foamed concrete (300x) with density $1600 \mathrm{~kg} / \mathrm{m}^{3}$ (a) without fibres Acontrol (b) with fibres - APP01.

Fig. 5(a) shows the microstructure of the foamed concrete with fibres at the part of failure after the split tensile strength test with the scale of $35 \mathrm{x}$. The PP fibres was being pulled out from foamed concrete and caused the crack in foamed concrete. Fig. 5(b) shows the image of microstructure of the PP fibres after test with the scale of 600x. There are some foamed concrete matrix left on the PP fibres, which can observed in the red circle in Fig. 5(b). It means that there was an interfacial adhesion between the foamed concrete and PP fibres. Through the study of tensile strength of foamed concrete with various percentage of PP fibres, it was found that the $0.05 \%$ of PP fibres showed the best interfacial adhesion, which gave the optimum tensile strength.

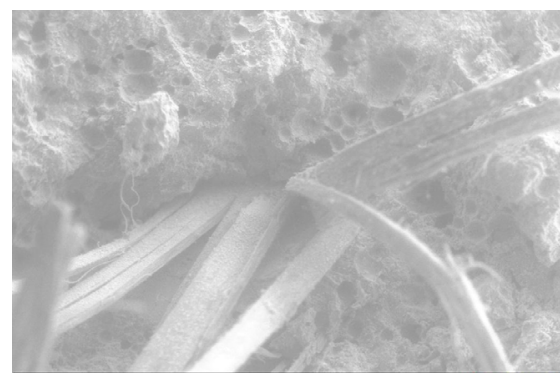

(a)

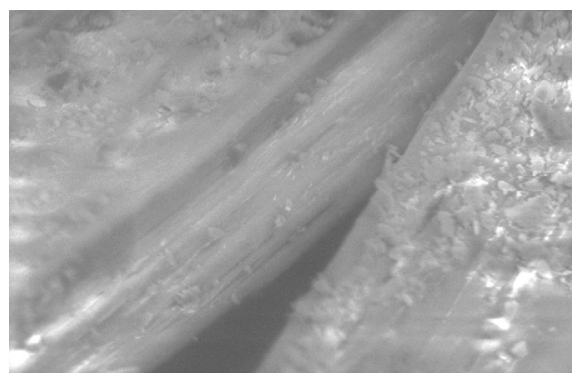

(b)

Fig. 5. (a) Microstructure of the foamed concrete with fibres at the part of failure (35x) (b) Microstructure of the PP fibres after being pull out from foamed concrete (600x).

\section{Conclusions}

From the results if research, as well as data analysis and discussion, it can be concluded as follows:

i) The tensile strength of target density $1800 \mathrm{~kg} / \mathrm{m}^{3}$ foamed concrete was higher than the target density $1600 \mathrm{~kg} / \mathrm{m}^{3}$ foamed concrete. The higher the density of foamed concrete, the higher its strength.

ii) The tensile strength of foamed concrete with PP fibres was higher than the foamed concrete without PP fibres. The optimum percentage of PP fibres as additive in foamed concrete for both $1600 \mathrm{~kg} / \mathrm{m}^{3}$ and $1800 \mathrm{~kg} / \mathrm{m}^{3}$ density was $0.05 \%$. 
iii) Through the study of microstructure of foamed concrete, the air voids of $1600 \mathrm{~kg} / \mathrm{m}^{3}$ foamed concrete was found to have bigger size compared to $1800 \mathrm{~kg} / \mathrm{m}^{3}$ foamed concrete. Besides that, the interfacial adhesion between the foamed concrete and PP fibres was observed.

iv) The actual density of the samples had higher density compared to the target density. It was difficult to achieve the target density since there were a lot of unpredictable elements during mix work and environment factors.

The authors would like to thank the Universiti Tun Hussein Onn Malaysia and Ministry of Higher Education Malaysia (FRGS-VOT 1525) for their financial support for this project.

\section{References}

[1] M. Jones and A. McCarthy, Preliminary views on the potential of foamed concrete as a structural material. Magazine of Concrete Research, 57(1), 21-31, (2005)

[2] A. Neville and J. Brooks, Concrete technology. England: Prentice Hall, England, (2001)

[3] A.H. Ameer, H.T. Nicholas and R.D. Andrew, The use of additives to enhance properties of pre-formed foamed concrete, IACSIT International J. of Engineering and Technology, 7(4), 286-293 (2015)

[4] A. Laning, Primarily used to reduce shrinkage cracking, polypropylene, nylon, and polyester fibers offer other benefits as well, Article on Concrete Construction, The Aberdeen Group, (1992)

[5] J.E. Shoenberger and J. G. Tom, Polypropylene fibres in portland cement concrete pavements, Washington, (1992)

[6] Z. Deng and J. Li, tension and impact behaviours of new type fibre reinforced concrete, Computers and Concrete, 4(1), 19-32, (2007)

[7] BS EN 12350-6, Testing fresh concrete density, British Standard Institution, London, (2000)

[8] BS EN 12390-6, Testing hardened concrete part 6: Tensile splitting strength of test specimens, British Standard Institution, London, (2009)

[9] K.M. Nemati, Fracture analysis of concrete using scanning electron microscopy, Scanning, 19, 426-43, (1997)

[10]K. Ramamurthy, E. Kunhanandan Nambiar and G. Indu Siva Ranjani, A classification of studies on properties of foam concrete, Cement \& Concrete Composites, 31, 388396, (2009)

[11]Chen Bing, Wu Zhen and Liu Ning, Experimental research on properties of highstrength foamed concrete, J. Mateias in Civil Engineering, 24, 113-118, (2012)

[12]N.F. Medina, G. Barluenga and F. Hernandez-Olivares, Combined effect of polypropylene fibres and silica fume to improve the durability of concrete with natural pozzolans blended cement, Construction and Building Materials, 96, 556-566, (2015)

[13]J. Hadipramana, A. Abdul Samad, A. Ahmad Zaidi, Noridah Mohammad and N. Ali, Contribution of polypropylene fibre in improving strength of foamed concrete, Advanced Materials Research, 626, 762-768, (2013) 